\title{
THE VISIT FEES AND ITS INFLUENCE ON OVERALL HEALTH EXPENDITURES - THE CASE OF THE CZECH REPUBLIC
}

\author{
J. Stephen Clark, Ludwig O. Dittrich, Dana Stará, Miroslav Barták
}

\section{Introduction}

One of the most common problems with health care systems around the world is that the cost of running them tends to increase at higher rate than the rate of inflation (see Glied \& Smith, 2013). This has led among others to the introduction of visit fees by governments and/or public as well as private health care facilities and other health care providers. According to the last available data health spending is estimated to have increased by $1.0 \%$ in real terms across OECD countries in 2013, up from $0.7 \%$ in 2012 and near-zero growth in 2010. However, growth rates in 2013 remained well below pre-crisis levels: between 2000 and 2009 average growth in health spending reached $3.8 \%$ (OECD, 2015). Co-payments for physician services are common in high-income countries and are also considered in middle income countries of the Central and Eastern Europe (CEE) (Danyliv et al., 2013; Paris et al., 2010; 2016). Many high income countries increased the level of the patient cost sharing between 2000 and 2010 as a part of policy measures to reduce the level of health care spending (Zare \& Anderson, 2013). In spite of higher levels of cost-sharing, out-of-pocket spending as a percentage of total spending remained unchanged in most of these countries because they instituted programs to protect certain categories of individuals. They achieved that by setting out-of-pocket limits, exempting people with certain chronic diseases, or eliminating cost sharing for certain demographic groups and low-income people (Zare \& Anderson, 2013). These fees are meant to rationalize the use of the health care system and slow the growth of health care expenditures. There are also another ways how to rationalize a health care delivery system. Those include for example the substitution of ambulatory care for hospital care and promoting the system of oneday surgeries (Gavurova \& Soltes, 2016).
Based on law no 261/2007 Coll. (Public budgets stabilization act) the regulatory fees - afterword referred in the article as visit fees were introduced in the Czech Republic as a new article $16 \mathrm{a}$ and $16 \mathrm{~b}$ of the law no $48 / 1997$ Coll. (Public health insurance act) and come into force from $1^{\text {st }}$ January 2008. This fixed consumer copayments on doctors' visits, hospital stay, use of medical emergency rooms and the prescription of drugs. The Ministry of Health of the Czech Republic argued in 2007 and 2008 (Ministry of Health, 2009) that visit fees would discourage the consumption of unnecessary care and fees will be another source of financing of costly care and technologies.

The effectiveness of fees to achieve those objectives was widely discussed among general public, in academic circles and within policy making authorities at national, regional and local level with media taking a strong interest in the debate (Gavurova \& Vagasova, 2016). Fees structure was changed several times between 2008 and 2014, as a result of political decisions of the government as well as by decision of the Constitutional Court of the Czech Republic (fee for hospital stay). Regulatory fees with exception of the fee for visit of medical emergency rooms were abolished by the amendment to the Public health insurance act from $1^{\text {st }}$ January 2015.

The goal of the study is to develop a simple demand model of health care services that can explain why the demand for health care services, and hence overall expenditures on health care, can rise with the introduction of visit fees based on real data available publicly in the Czech Republic.

The model provides an explanation of findings that were presented in the paper of Dittrich and Stará in 2013. The data used for the Dittrich and Stará (2013) analysis were published in the official publication of the Czech Statistical Office (CZSO) - Results of Health 
Accounts of the Czech Republic (CZSO, 2013).

Another goal is also fill the research and publication gap that may be found in the domestic academics literature.

\section{Literature Review}

Some analysis of the fee impact were elaborated in the Czech Republic (e.g. Zápal, 2010; Tučková, Fialová, \& Popesko, 2012; Krůtilová \& Yaya, 2012; Žílová \& Votápková, 2012; Dittrich \& Stará, 2013; Pražmová, 2014). The papers differ both in methods, data and covered time period and thus the outcome varies. Krütilová (2010) argues that effect of user fees depends on the type of services; it is very strong and persisting regarding luxury services (visit of general practitioners in patient home), strong with weakening tendency for ordinary services (outpatient services, medication) and relatively weaker for inpatient services. When it comes to gender, user fees influenced the demand of female patients for care much more than male patients. The regulatory effect seems to be much weaker among seniors than among other observed age groups particularly in the second year after the implementation of user fees. In other groups (excluding infants) the regulatory effect tends to persist. Zápal (2010) using child drug consumption as a proxy for the number of children's doctor visits, found no effect of the reform. Krůtilová and Yaya
(2012) found that fees may create financial obstacles for some households and restrict the desirable consumption of health care. Results showed that the health care spending burden of households increased from $2.15 \%$ of their net income to $2.63 \%$ in 2008 and to $2.55 \%$ in 2009 after the implementation of user fees. Krůtilová and Yaya (2012) noted that the presence of pensioners and elderly in a household was the factor which increased the overall burden. Žilová and Votápková (2012) in their paper presented two economic models and their results show an insignificant effect of the abolition of user charges on the number of doctor visits, i.e. the probability of visiting a doctor among the members of treatment group (children) did not significantly change when user charges were abolished. Pražmová (2014) research has shown that the introduction of fees led to the reduction of the total number of doctor visits. Sixteen out of twenty-two surveyed specialties after 2008 show a statistically significant decrease in visits.

Dittrich and Stará (2013) research used aggregate data for years 2003 to 2011 (see UZIS (2013); CZSO (2014)) on health care expenditures and number of visits and the authors found that visit fees indeed reduced number of outpatient visits on the average by $2.5 \%$ per year, but the lower number of visits did not translate to lower insurance system expenditures on outpatient care. On the contrary,

\section{Tab. 1: Regulatory fees in the research evidence in the Czech Republic - Part 1}

\begin{tabular}{l|l|l} 
Author(s) & Year & \multicolumn{1}{c}{ Findings } \\
\hline Zápal & $2010 \begin{array}{l}\text { Using child drug consumption as a proxy for the number of children's doctor } \\
\text { visits, found no effect of the reform. On the other hand, the data reveal a short- } \\
\text { term strategic timing effect associated with the policy change. With the policy } \\
\text { effective since April 2009, there is evidence of a shift in children's doctor visits } \\
\text { away from March towards April. However, he was not able to fully disentangle } \\
\text { the potential confounding effect of the spring vacation and as a result are much } \\
\text { less convinced of this result. }\end{array}$ \\
\hline Krůtilová & $2010 \begin{array}{l}\text { The effect of user fees depends on the type of services; it is very strong and } \\
\text { persisting regarding luxury services (visit of general practitioners in patient } \\
\text { home), strong with weakening tendency for ordinary services (outpatient } \\
\text { services, medication) and relatively weaker for inpatient services. When it } \\
\text { comes to gender, implemented user fees influenced the demand of female } \\
\text { patients much more than male patients. The regulatory effect seems to } \\
\text { be much weaker among seniors than among other observed age groups } \\
\text { particularly in the second year after the implementation of user fees. In other } \\
\text { groups (excluding infants) the regulatory effect tends to persist. }\end{array}$ \\
\hline
\end{tabular}


Tab. 1: Regulatory fees in the research evidence in the Czech Republic - Part 2

\begin{tabular}{|c|c|c|}
\hline Author(s) & Year & Findings \\
\hline $\begin{array}{l}\text { Tučková, } \\
\text { Fialová, } \\
\text { \& Popesko }\end{array}$ & 2011 & $\begin{array}{l}\text { From the health care analysis after the introduction of regulatory fees is clear } \\
\text { that the introduction of fees has brought far more positive than negative. } \\
\text { People obviously disagreed with the introduction of fees and still disagree, but } \\
\text { some are starting to realize the positive impact of regulatory fees. The health } \\
\text { care system has long been in a bad economic situation and the introduction of } \\
\text { fees was one of the steps that can help health care, at least a little. }\end{array}$ \\
\hline $\begin{array}{l}\text { Pražmová } \\
\text { \& Dušek }\end{array}$ & 2011 & $\begin{array}{l}\text { Research results proved that most respondents are not in favour of area } \\
\text { cancelation of regulatory fees but they are in favour of modifying them. The } \\
\text { most acceptable is the regulatory fee for hospital stay per day, on the other } \\
\text { hand, the worst evaluated is the fee for each item on prescriptions. The } \\
\text { implemented regulatory fees led to the decrease of visits at the doctor's with } \\
28 \% \text { of respondents. }\end{array}$ \\
\hline $\begin{array}{l}\text { Krůtilová } \\
\text { \& Yaya }\end{array}$ & 2012 & $\begin{array}{l}\text { As a part of the health care reform package in } 2008 \text {, some additional out-of } \\
\text { pocket payments were introduced, called 'user (patient) fees'. Furthermore, } \\
\text { the government intends to increase some user fees in the following years. } \\
\text { There have been serious discussions between proponents and opponents } \\
\text { because an increase in out of pocket payments for health care may create } \\
\text { financial obstacles for some households and restrict the desirable consumption } \\
\text { of health care. Results showed that the burden of households increased from } \\
2.15 \% \text { of their net income to } 2.63 \% \text { in } 2008 \text { and to } 2.55 \% \text { in } 2009 \text { after the } \\
\text { implementation of user fees. They noted that the presence of pensioners and } \\
\text { elderly in a household was the factor which increased the overall burden the } \\
\text { most and led to catastrophic payments. }\end{array}$ \\
\hline $\begin{array}{l}\text { Kinkorová } \\
\text { \& Topolčan }\end{array}$ & 2012 & $\begin{array}{l}\text { The share of private expenditure in the total expenditure on health rose } \\
\text { particularly after 2008, due to new regulation fees in health services. In } \\
2010 \text { the private expenditure on health slightly decreased, partly as a result } \\
\text { of softening of the regulation fees and of stagnant purchasing power of the } \\
\text { population. }\end{array}$ \\
\hline $\begin{array}{l}\text { Žílová } \\
\text { \& Votápková }\end{array}$ & 2012 & $\begin{array}{l}\text { Results of both models calculated by authors consistently show an insignificant } \\
\text { effect of the abolition of user charges on the number of doctor visits, i.e. } \\
\text { the probability of visiting a doctor among the members of treatment group } \\
\text { (children) did not significantly change when user charges were abolished. }\end{array}$ \\
\hline Pražmová & 2014 & $\begin{array}{l}\text { The research has shown that the established fees have led to a reduction } \\
\text { of the total number of visits at the doctor's. Sixteen of twenty-two surveyed } \\
\text { specialties after } 2008 \text { show a statistically significant decrease in visits. Their } \\
\text { announced cancellation, effective January } 1,2015 \text {, is unsystematic step } \\
\text { according to the author's meaning. }\end{array}$ \\
\hline $\begin{array}{l}\text { Pražmová } \\
\text { \& Talpová }\end{array}$ & 2014 & $\begin{array}{l}\text { The regulatory fees, which were introduced in the Czech Republic on } \\
01 / 01 / 2008 \text { are described in detail. Not only their economic function has been } \\
\text { emphasized, but also other aspects of the reform, especially the protective } \\
\text { limit, whose introduction ensures the availability of care for the chronically } \\
\text { ill and socially disadvantaged patients. The authors follow the evolution of } \\
\text { the price of all regulatory fees paid by all of the insured individuals of health } \\
\text { insurance companies in the Czech Republic for the period } 2008-2012 \text { and } \\
\text { the development of the amounts by which the protective limit was exceeded. } \\
\text { A comparison of patients' participation was carried out in selected European } \\
\text { Union countries, where the system has been in place for many years, together } \\
\text { with other protective mechanisms in order to provide health care for patients in } \\
\text { need. }\end{array}$ \\
\hline
\end{tabular}


total expenditure grew faster after the introduction of visit fees. While real billings per visit grew on average $4 \%$ per year before fees were introduced, after the introduction of fees real billings per visit grew on average $8.3 \%$ per year. In other words, the decline in the number of visits was more than offset by the shift to more numerous and expensive procedures during the visit (Dittrich \& Stará, 2013).

\subsection{Lesson Learned from Abroad}

The foreign literature on the effect of visit fees on health care expenditures has concentrated on the impact on the number of visits. Kim et al. (2005) found a fairly small decline in the number of visits following an increase in the visit fees. Chiappori et al. (1998) reports a negligible effect on the number of office visits after the visit fees are introduced. Schreyögg and Grabka (2010) reported that the introduction of visit fees in Germany in 2004 for the first visit in each quarter had little impact on the number of visits. While these studies all show a negative if small impact on the visits frequency with the introduction of visit fees they do not consider the impact that introduction of visit fees will have on other components of health care expenditure. The issue is also elaborated in Paul and Nielson (2014). An exception is a study by Jung (1998) that does not consider the impact of visit fees on visits in isolation, but reports an increase in intensity per visit.

The paper written by Aaltonen et al. (2013) explore trends and income related differences in out-of-pocket (OOP) costs for prescription and over-the-counter medicines in Finland in 1985-2006. They conclude that all patients faced increasing OOP payments for medicines throughout the study period, but the lowest income groups experienced largest relative increase in OOP payments. Their results suggest that savings achieved by increasing the patients' share of costs was accompanied by steeper growth in OOP costs and wider differences between income groups. Cost containment measures targeted at prices, on the other hand, coincided with stabilized OOP costs and decreasing dispersion between the income quintiles. (Aaltonen et al., 2013). The study by Baji et al. (2012) focuses on the shortterm effects of the introduction of the visit fee in Hungary in 2007 on informal patient payments. According to the results, $9 \%$ of the patients paid informally during their last visit to GP
(2 Euros on average), 14\% paid informally for specialist care (35 Euros on average) and 50\% paid informally for hospitalization (58 Euros on average). They find a significant reduction in the probability of informal payments only for elderly patients in the case of in-patient care. Their results suggest that informal payments are widely spread in Hungary, especially in inpatient care.

The short run potential of the introduction of the visit fee to reduce informal payments seems to be minor (Baji et al., 2012). According to the Laba et al. (2015) in Australia exists growing body of evidence highlighting the substantial economic burden faced by individuals and families as a result of out-ofpocket costs for health care and their effects on healthcare access, outcomes and long-term healthcare costs. It is argued that a compulsory minimum co-payment for GP consultations will exacerbate these burdens and significantly undermine the tenets of universal access in Australian Medicare.

Ma and Nolan (2016) used the longitudinal data from Ireland and found that introducing user fees for healthcare results in a significant decrease in GP visiting, while the removal of user fees results in a proportionately smaller, but still significant increase in GP visiting. They found little evidence of offset effects on other types of healthcare utilization that is, introducing user fees, principally for GP care, does not result in a significant change in the utilization of other types of healthcare such as hospital care. However, removing user fees for healthcare results in a significant increase in the number of medications dispensed.

\subsection{Elasticity of Health Care Demand}

Consumers have demand for health but cannot directly purchase it. They must purchase health care services that are used to produce health. The ideas that demand for health care is derived from the demand for health were first discussed by Grossman (1972). Regardless of empirical methods and data sources, the price elasticity of demand for the health care is found to be relatively inelastic. Although the price elasticity of demand for health care is relatively low (as Ringel et al. (2002) argue in large part because there are few close substitutes for medical services), certain types of care are found to be somewhat more price sensitive. Preventive care and pharmacy benefits are among those medical services with larger 
price elasticities. The finding that the demand for preventive care is more price sensitive than the demand for other types of care is not surprising. The number of available substitutes for a product is a major determinant of demand elasticity (see Ringel et al., 2002). As Zhou et al. (2011) and others (see the discussion in Ringel et al. (2002)) argue the elasticity of demand measures the responsiveness of demand for health care to changes in price or income.

Estimating the demand for health care services is a complex process that must consider both the consumer's response to changes in price and the provider's ability to induce demand (Weiner, 1993). Physicians may change their patterns of practice, perhaps prescribing more intense treatments, when increased cost-sharing leads to lower demand for their services. Furthermore, physicians act as an agent once care is initiated by the patient and may not consider price in the same way as the patient would (Ringel et al., 2002).

\section{Empirical Findings}

The paper of Dittrich and Stará (2013) used the aggregate data for years 2003 to 2011 on health care outpatient expenditures and the number of visits in the Czech Republic. They found that visit fees indeed reduced number of outpatient visits on the average by $2.5 \%$ per year, but the lower number of visits did not translate to lower insurance system expenditures on the outpatient care. To the contrary, total expenditure grew faster after the introduction of visit fees. While real billings per visit grew on average $4 \%$ per year before fees were introduced, after the introduction of fees real billings per visit grew on average $8.3 \%$ per year. Below we introduce a simple demand model for health care services that can explain the observed acceleration in the growth of the outpatient expenditures in the Czech Republic after regulation fees were introduced.

\section{Model}

The simple demand model of health care services is presented that can explain why the demand for health care services, and hence overall expenditures on health care, can rise with the introduction of visit fees was developed with the following parameters.

Let $P$ be the price index of health care services and let $Q$ be the quantity of health care services. Then the consumer problem is to

$$
\text { Max. } U(Q) \text { s.t. } P Q=E \text {, }
$$

where $E$ is expenditures on health care services. The model outlined in equation (1) describes the demand side of the health care market for in a private system where the consumer pays for health care services directly to the doctor. In a system where consumers do not pay doctors directly, health care expenditures would likely spin out of control since neither the doctors nor the consumers are paying for health care services.

Suppose the government wants to slow the growth of health care expenditures by imposing a visit fee on outpatient visits. In other words, the government charges consumers on the basis of a price per visit. Define $V$ as doctor visits, and let

$$
Q=\gamma V
$$

where $y$ is health care "intensity" per visit. Define $P^{*}$ is the price of a visit. The introduction of a visit fee $P^{*}$ has increased a component price of $P$, but has left other components unchanged. Expenditure on health care services is given by the identities

$$
E=P Q=P \gamma V \text {. }
$$

Define $\varepsilon^{Q P^{*}}$ as the elasticity of demand of health services with respect to the price of visits, $\mathrm{P}^{*}, \varepsilon^{\mathrm{VP}}$ as the elasticity of demand of visits with respect to $P^{*}$ and $\varepsilon^{\mathrm{PP}^{*}}$ as the elasticity of demand of visit intensity with respect to $P^{*}$. Differentiating the natural logarithm of equation (2) by the natural logarithm of $P^{*}$ then

$$
\varepsilon^{Q P^{*}}=\varepsilon^{V P^{*}}+\varepsilon^{\gamma P^{*}},
$$

if $\varepsilon^{Q P^{*}}>0$ in equation (4) then health care expenditures will rise with the introduction of visit fees. From equation (4), the elasticity of demand for health care with respect to $\mathrm{P}^{*} \varepsilon^{\mathrm{QP}}$, is the sum of two elasticities: 1) the own price elasticity for number of visits $\left(\varepsilon^{\mathrm{VP}^{*}}\right)$; and 2 ) the cross price elasticity of visit intensity $\left(\varepsilon^{\mathrm{YP}^{*}}\right)$.

\section{Results}

The own price elasticity for number of visits is negative and it is this elasticity that the government probably had in mind when it introduced the visit fee as a method to reduce health care expenditures E. However, as 
equation (4) demonstrates, the total effect on the demand for health care services $Q$ resulting from an increase the visit fee depends not only on the effect the visit fee will have on visits $\mathrm{V}$, but also the effect the visit fee has on visit intensity $\mathrm{Y}$. The intensity elasticity measures the effect a change in the price of visits has on the visit intensity and, given equation (3), is positive, since visits and visit intensity are substitutes. If the cross price of intensity elasticity $\left(\varepsilon^{\mathrm{YP}^{\mathrm{P}^{*}}}\right)$ is elastic, and the own price elasticity of visits $\left(\varepsilon^{V P^{*}}\right)$ is inelastic, then the overall effect of the introduction of visit fees is to increase the demand for health care services $Q$. Stated more generally, the elasticity of health care services will be positive with the introduction of visit fees whenever the cross price elasticity of health care intensity with respect to the price of visits is larger in absolute value than the own price elasticity of visits with respect to the price of visits. A graphical representation of the demand shift for visit intensity is given by Fig. 1 . The demand for visit intensity rises from D1 to D2. Since the price of visit intensity has not changed, the quantity of visit intensity increases from Q1 to Q2, increasing overall health care expenditures by $\mathrm{P}$ (Q2-Q1).

\section{Fig. 1: Price and quantity of visit intensity}

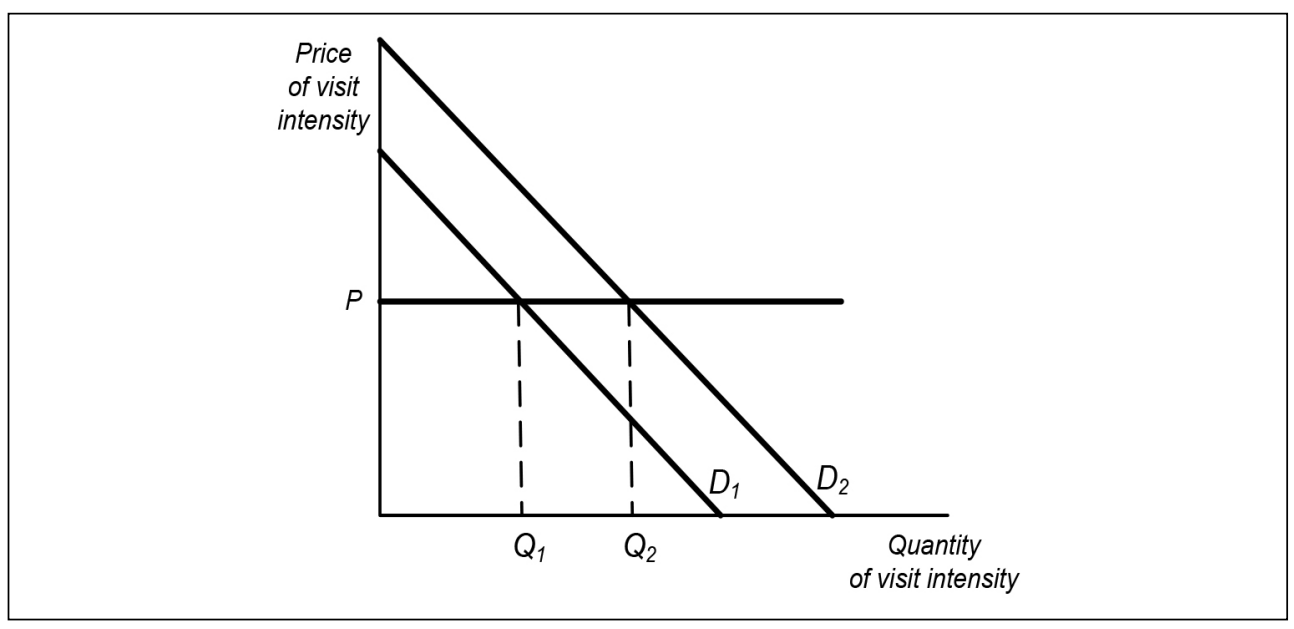

Source: own

The effect of visit fee on overall expenditures on health care depends on the sign of

$$
d \ln E / d \ln P^{*}=d \ln P / d \ln P^{*}+\varepsilon Q P^{*},
$$

with expenditures rising whenever (5) is greater than zero. The first term on the right hand side of equation (5) is positive and measures the increase in the overall price of health care services $P$ resulting from an increase in the introduction of a visit fee $P^{*}$. If the price of visits $P^{*}$, is a small component of the overall price of health care services $P$ or the price change in $P^{*}$ itself is small, this effect is likely to be small. In contrast, the discussion until now has focused on why $\varepsilon^{\mathrm{QP}^{*}}$ is positive, and so charging a visit fee will increase total expenditures on health care from equation (5).

Fig. 1 coupled with equation (5) demonstrates why the introduction of visit fees may not lead to a decline in health care expenditures. An unambiguous way to lower the demand for health care services is to increase the price of $P$. Instead, the government increases one component of $\mathrm{P}$, the visit fee $\mathrm{P}^{*}$, leaving the rest of the components (summarized in the price of intensity in Fig. 1) unchanged. Therefore, consumers shift from visits to visit intensity, resulting in a rise in health care expenditures. This shift between number of visits and visit 
intensity has also been noted in health care literature by Jung (1998) and in the all-you-caneat food literature by Just and Wansink (2010).

Visits and visit intensity are substitutes. The introduction of a visit fee heightens the awareness of this substitution in the mind of the consumer and increases the desire of consumers for more health care intensity. One can imagine the thought process of consumers when they are required to pay a visit fee: "Now that I have to pay for my visit, I want to get my money's worth in terms of more services per visit". One can also imagine the thought process of doctors when confronted with consumers who want better visit intensity: "Well in that case, we should do more testing, monitoring, etc. each time you are here". It could actually be in the reverse with the doctor saying to the patient something like: "Since you will visit less often, we need to make sure we do more and better testing, monitoring etc. with each visit". This is an example of the supplier induced demand e.g. Evans (1974). The result could easily mean an increase in overall health care expenditures.

The visit reservation price is the visit price at which the health care consumer would quit going to the doctor entirely. The discussion up to this point assumes that the health care consumer will respond to an increase the visit fee by reducing visits but that these visits are not reduced to zero. For some consumers, a doctor visit reservation price is reached so that this consumer will quit going to the doctor entirely. Given the modest size of the visit fees introduced, this reservation price is unlikely to be reached for any but the poorest health care consumers.

Both visits and visit intensity will fall to zero when the reservation price is reached. This would lead to an unambiguous fall in health care expenditures, at least in the short term. In this case the introduction of a visit fee is effective in reducing health care expenditures. However the targeting of its poorest citizens to ensure the effectiveness of its policy to reduce health care expenditures through the reduction of all (except perhaps emergency) health care services to zero is unlikely to be the intended purpose of the introduction of visit fees. Over the longer term, since these health care consumers receive no ongoing medical treatment, monitoring and advice, their health may suffer and put preventable costs on the health care services in the future.

\section{Discussion}

The proposed model explains finding by Dittrich and Stará (2013) of the acceleration in billing for outpatient services after visit fees were introduced. On the other hand, as the majority of fees were abolished from 1st January 2015 the possibility of further verification is therefore applicable for data from 2014 only. The government needs a rationing device to control expenditures. It chooses to increase the visit price to consumers as a rationing device. In doing so, the government assumes that consumers do not respond to the increase in the visit price by changing visit intensity, which of course they do. If the price of visits rises and there is no change in the price of the rest of health care goods and services, then consumers will demand more health care services per visit. The increase in expenditures on these services may more than offset the decline in expenditures resulting from fewer visits, rendering the introduction of a visit fee a counterproductive rationing device to control health care expenditures.

The main factors that determine health care expenditure are technology (highest share), administrative cost, changes in financing, healthcare prices, increasing life expectancy and ageing of the population and personal income growth. The assumptions vary considerably but the technology have highest share in all researches done in previous years. The healthcare prices have share on increases from $11-22 \%$ according to the research evidence (for details e.g. Ivlev, Kneppo, \& Barták, 2014).

We have to take into account also that physicians may change their patterns of practice, perhaps prescribing more intense treatments, when increased cost-sharing leads to lower demand for their services. Furthermore, physicians act as an agent once care is initiated by the patient and may not consider price in the same way as the patient would. There is evidence that ineffectiveness is also the attribute of supply side and third party payers (health insurance funds).

\section{Conclusion}

The model shows that the demand for health care services will increase with an increase in the price of visits when the cross price elasticity of demand for visit intensity outweighs the own price elasticity of visits. The introduction of a visit 
fee is a counterproductive rationing device for health care services if it rations a component of overall health care services with a low own price elasticity of demand without rationing a substitute variable (visit intensity) with a higher cross elasticity of demand. Thus, the introduction of a visit fee may induce a sense of entitlement for further health care services per visit on the part of consumers, leading to an increase in overall health care expenditures. The model suggests that if the government wants to use the visit fee as a rationing device to lower health care expenditure, then it needs to find a way to ration also the visit intensity both from the point of view of patients as well as medical doctors.

\section{References}

Aaltonen, K. et al. (2013). Trends and income related differences in out-of-pocket costs for prescription and over-the-counter medicines in Finland from 1985 to 2006. Health Policy, 110(2-3),131-140. doi:10.1016/j. healthpol.2012.12.004.

Baji, P. et al. (2012). Informal payments for healthcare services and short-term effects of the introduction of visit fee on these payments in Hungary. Int. J. Health Plann. Mgmt., 27(1), 63-79. doi:10.1002/hpm.1106.

CZSO. (2013). Results of Health Accounts of the Czech Republic 2000-2012. Retrieved from https://www.czso.cz/csu/czso/vysledkyzdravotnickych-uctu-cr-2000-az-2012efsq7vjwwi.

Czech Republic. (1997). Law no 48/1997 Coll. Public Health Insurance. Retrieved from https://portal.gov.cz/app/zakony/zakon. jsp?page $=0$ \&nr=48 2F1997\&rpp=15\#seznam.

Czech Republic. (2007). Law no 261/2007 Coll. Public budgets stabilization act. Retrieved from https://portal.gov.cz/ app/zakony/zakon.jsp?page $=0 \& n r=$ 261 2F2007\&rpp=15\#seznam.

Chiappori, P.-A. et al. (1998). Moral hazard and the demand for physician services: first lessons from a French natural experiment. European Economic Review, 42(3-4), 499-511. doi:10.1016/S0014-2921(98)00015-4.

Danyliv, A. et al. (2013). Willingness to pay for physician services at a primary contact in Ukraine: results of a contingent valuation study. BMC Health Services Research, 13(208). doi:10.1186/1472-6963-13-208.
Dittrich, L. O., \& Stará, D. (2013). Regulation Fees and Health Care Spending. IntAdvEcon, 20(2), 237-238. doi:10.1007/s11294-013-9443-y.

Evans, R. G. (1974). Supplier-Induced Demand. In M. Perlman (Ed.), The Economics of Health and Medical Care (pp. 162-173). London: Macmillan.

Gavurova, B., \& Soltes, M. (2016). System of Day Surgery in Slovakia: Analysis of pediatric Day Surgery Discrepancies in the Regions and their Importance in Strategy of its Development. E\&M Ekonomie a Management, 19(1), pp. 7492. doi:10.15240/tul/001/2016-1-006.

Gavurova, B., \& Vagasova, T. (2016). Regional differences of standardised mortality rates for ischemic heart diseases in the Slovak Republic for the period 1996-2013 in the context of income inequality. Health Economics Review, 6(21). doi:10.1186/s13561-016-0099-1.

Glied, S., \& Smith, P. C. (Eds.). (2013). The Oxford Handbook of Health Economics. Oxford: Oxford University Press.

Grossmann, M. (1972). On the Concept of Health Capital and the Demand for Health. Journal of Political Economy, 80(2), 223-255.

Ivlev, I., Kneppo, P., \& Barták, M. (2014). Multicriteria decision analysis: a multifaceted approach to medical equipment management. Technological and Economic Development of Economy, 20(3), 576-589. doi:10.3846/202949 13.2014.943333.

Jung, K. (1998). Influence of the introduction of a per-visit copayment on health care use and expenditures: The Korean experience. The Journal of Risk and Insurance, 65(1), 33-56. doi:10.2307/253490.

Just, D. R., \& Wansink, B. (2011). The flat rate pricing paradox: Conflicting effects of "All-You-Can-Eat" buffet pricing. Review of Economics and Statistics, 93(1), 193-200. doi:10.1162/REST_a_00057.

Kossarova, L., \& Madarova, H. (2008). Czech Republic: First steps on the path to health care reform. EuroHealth, 14(4), 10-12.

Kim, J. et al. (2005). The effects of patient cost sharing on ambulatory utilization in South Korea. Health Policy, 72(3), 293-300. doi:10.1016/j.healthpol.2004.09.002.

Kinkorová, J., \& Topolčan, O. (2012). Overview of healthcare system in the Czech Republic. EPMA Journal, 3(4). doi:10.1007/ s13167-012-0139-9.

Krutilová, V. (2010). Impact of user fees in health care system on health care 
consumption. Národohospodářský obzor Review of Economic Perspectives, 10(4), 113132. doi:10.2478/v10135-011-0001-3.

Krůtilová, V., \& Yaya, S. (2012). Unexpected impact of changes in out-of-pocket payments for health care on Czech household budgets. Health Policy, 107(2-3). 276-288. doi:10.1016/j. healthpol.2012.07.002.

Laba, T. L. et al. (2015). Co-payments for health care: what is their real cost? Aust. Health Review, 39(1), 33-36. doi:10.1071/AH14087.

Ma, Y., \& Nolan, A. (2016). Public Healthcare Entitlements and Healthcare Utilization among the Older Population in Ireland. Health Econ. doi:10.1002/hec.3429.

Ministry of Health Czech Republic. (2009). Press Release: Regulatory fee brings the total saving of 10 billion CZK, that was invested into previously limited and costly care for severe ill. Retrieved from http:// www.mzcr.cz/dokumenty/tiskova-zpravaregulacni-poplatky-prinesly-celkovou-usporumiliard-korun-ktera-se-investovala-do-driveomezene-dostupne-a-nakladne-lecby-vaznenemocnych_1259_868_1.html.

OECD. (2015). Focus on health spending OECD Health statistics. Retrieved from http:// www.oecd.org/health/health-systems/FocusHealth-Spending-2015.pdf.

Paul, A., \& Nilsson, A. (2014). The Effect of Copayments on Children's and Adolescents' Demand for Medical Care. Beiträge zur Jahrestagung des Vereins für Socialpolitik Evidenzbasierte Wirtschaftspolitik - Session: Health III, No. C10-V2. Retrieved from http:// hdl.handle.net/10419/100403.

Paris, V., Devaux, M., \& Wei, L. (2010). Health Systems Institutional Characteristics: A Survey of 29 OECD Countries [OECD Health Working Papers, No. 50]. Paris: OECD Publishing. doi:10.1787/5kmfxfq9qbnr-en.

Paris, V. et al. (2016). Health care coverage in OECD countries in 2012 [OECD Health Working Papers, No. 88]. Paris: OECD Publishing. doi:10.1787/5jlz3kbf7pzv-en.

Pražmová, V., \& Dušek, K. (2011). Outcome of regulatory fees in healthcare. Journal of Nursing, Social Studies and Public Health. 2(1-2), 60-72.

Pražmová, V. (2014). The impact of regulatory fees on the number of patient visits at the doctor's. Journal of Nursing, Social Studies, Public Health and Rehabilitation. 3-4, 133-142.

Pražmová, V., \& Talpová, E. (2014). Health financing and regulatory fees in the
Czech Republic. Kontakt, 16(3), e187-e194. doi:10.1016/j.kontakt.2014.08.003.

Ringel, J. S., Hosek, S. D., Vollaard, B. A., \& Mahnovski, S. (2002). The elasticity of demand for health care; $A$ review of the literature and its application to the military health system. National Defense Research Institute, RAND Health. Retrieved from http://www.rand. org/content/dam/rand/pubs/monograph_ reports/2005/MR1355.pdf.

Schreyögg, J., \& Grabka, M. M. (2010). Copayments for ambulatory care in Germany: a natural experiment using a difference-indifference approach. European Journal of Health Economics, 11(3), 331-341. doi:10.1007/ s10198-009-0179-9.

Tučková, Z., Fialová, Š., \& Popesko, B. (2011). Regulatory Fees - Suitable Way for Czech Health Care Management? In M. Lazard et al. (Eds.), Recent Advances in Applied \& Biomedical Informatics and Computational Engineering in Systems Applications (pp. 311316). Florence.

Zápal, J. (2010). Doctor-Visit Co-Payment Exemption for Children: First Look at the Data. Finance a úvěr-Czech Journal of Economics and Finance, 60(1), 58-72.

Zare, H., \& Anderson, G. (2013). Trends in cost sharing among selected high income countries-2000-2010. Health Policy, 112(1), 35-44. doi:10.1016/j.healthpol.2013.05.020.

Zhou, Z., Su, Y., Gao, J., Xu, L., \& Zhang, Y. (2011). New estimates of elasticity of demand for healthcare in rural China. Health Policy, 103(2-3), 255-265. doi:10.1016/j. healthpol.2011.09.005.

Žilová, P., \& Votápková, J. (2012). The effect of the abolition of user charges on the demand for ambulatory doctor visits [IES Working Paper, 30/2012]. Prague: IES FSV, Charles University. Retrieved from http://ies.fsv. cuni.cz/sci/publication/show/id/4783.

prof. J. Stephen Clark, Ph.D. Delhausie University Department of Economics jsclark@dal.ca

PhDr. Ludwig O. Dittrich, Ph.D. Czech University of Life Sciences Prague Department of Economic Theories dittrich@pef.czu.cz 
Ing. Dana Stará, Ph.D. Czech University of Life Sciences Prague Department of Economic Theories starad@pef.czu.cz
PhDr. Miroslav Barták, Ph.D. J. E. Purkyně University in Ústí nad Labem Faculty of Social and Economic Studies Department of Social Work miroslav.bartak@ujep.cz 


\title{
Abstract
}

\section{THE VISIT FEES AND ITS INFLUENCE ON OVERALL HEALTH EXPENDITURES - THE CASE OF THE CZECH REPUBLIC}

\author{
J. Stephen Clark, Ludwig O. Dittrich, Dana Stará, Miroslav Barták
}

The goal of the paper is to develop a simple demand model of health care services that can explain why the demand for health care services, and hence overall expenditures on health care, can rise with the introduction of visit fees based on real data available publicly in the Czech Republic. One of the most common problems with the costs of health care systems around the world is that they tend to increase expenditures at a rate that is greater than the rate of inflation. This has led to the introduction of visit fees by governments and/or public, private health care facilities and other health care providers. These fees are meant to rationalize the use of the health care system and slow the growth of health care expenditures. The Ministry of Health of the Czech Republic introduced from $1^{\text {st }}$ January 2008 visit fees as a way to slow the growth of health care expenditures. On the contrary, total health care expenditures increased after the introduction of visit fees. A model of visits and visit intensity is developed, where visits and visit intensity are substitutes. The model shows that the demand for health care services will increase with an increase in the price of visits when the cross price elasticity of demand for visit intensity outweighs the own price elasticity of visits. The fees were abolished with the exception of fee for emergency room visit from 2015. The introduction of a visit fee is a counterproductive rationing device for health care services if it rations a component of overall health care services with a low own price elasticity of demand without rationing a substitute variable (visit intensity) with a higher cross elasticity of demand. Thus, the introduction of a visit fee may induce a sense of entitlement for further health care services per visit on the part of consumers, leading to an increase in overall health care expenditures.

Key Words: Health care, demand price elasticity, visit fees, service intensity, rationing device.

JEL Classification: /18.

DOI: 10.15240/tul/001/2017-2-001 